\title{
BEYOND ‘OTHERING’: THE POLITICAL ROOTS OF SLUM TOURISM
}

\author{
Fabian Frenzel
}

\begin{abstract}
The occurrence of organized forms of slum tourism in at least two cities of the global South has been linked to large-scale political events, involving thousands of political travellers. Rio de Janeiro's favela tours are said to have originated in the 1992 Rio Earth Summit (Freie Medeiros 2009) while Nairobi's Kibera Tours originated in tours taken by attendees of the 2007 World Social Forum (Mowforth \& Munt 2009). Township tourism in South Africa was preceded by politically motivated 'struggle junkies' who visited townships in support of the resistance of black South Africans against the apartheid regime.
\end{abstract}

This indicates the particular role of mobile political activists in the creation of slum tourism as an organized tourist practice. Moreover, these cases seem to indicate a development pattern of slum tourism destinations, which could help explain the process through which they come about.

In this chapter I situate slum tourism in the wider realm of the political tourism that arguably triggered its development. As mobile political activists visit slums they often intend political transformations of the slum and attempt to create networks of solidarity with the visited slum dwellers. Does this political nature of the visits survive in the development of slum tourism in the given destinations? By looking at the links between slum tourism and political tourism, this chapter addresses the ethical concerns central to slum-tourism reflections. 


\section{Introduction}

Slum tourism is a growing phenomenon in global tourism. It describes organized tours to deprived areas. Having a long history (Koven 2004; Steinbrink 2012; Seaton in this volume), contemporary slum tourism in the global South first occurred in post-apartheid South Africa in the form of so-called 'township tours', and shortly after in Brazil as favela tourism in Rio de Janeiro (Freire-Medeiros 2009; Rolfes 2009). Although recently slum tourism has developed in many more places, it is important to note that slum tourism does not occur in every poor area of the world. Often, the development seems to be triggered by certain events and specific social-cultural contexts. One of the central issues for slum tourism research is to better understand these specific conditions - for example, by highlighting commonalities between specific cases. A commonality I would like to focus on in this chapter is the role of politically motivated travellers, or what has been called 'political tourists' (Frenzel 2009; Babb 2004; Brin 2006; Henderson 2007; Moynagh 2008) or 'justice tourists' (Scheyvens 2002; Pezzullo 2007). While there is no set definition of political tourists, it broadly describes people who travel for political purposes or out of political interests. This includes globally mobile political activists with high levels of involvement either with the politics of visited countries or transnational political alliances. It also includes globally mobile volunteers and non-interventionist, politically interested tourists. Forms of political tourism have occurred for some time, and have often involved visits of better-off travellers to people living in poverty. Among other things, these visits have been motivated by solidarity with the poor and were intended to build political alliances across national borders and class boundaries. Today, people travelling to take part in events of the global justice movement, like the World Social Forum (WSF) or international summit protests, demand higher global social equality or wish to ‘make poverty history’ (Gumbel 2005). 
In this chapter I focus on the role travelling activists have played in the genesis of three particular slum tourism destinations: two highly developed cases in South Africa and Brazil and one in the less-developed destination of the Kibera slum in Nairobi, Kenya. Reflecting on the differences and overlaps between these three cases, this chapter argues that the development of slum tourism between them follows a certain pattern. This result prompts the question whether this pattern might be applicable to other cases.

In a second, related argument I reflect further on the apparent link between the travels of political tourists and slum tourism. If there is a connection between the two, how can it be interpreted? Can slum tourism be understood as a commercialization of activist travel? Do political intentions remain relevant in the case of slum tourism even after commercialization? In addressing these questions, I seek to contribute to the debate on the ethics of slum tourism. More than other forms of tourism, slum tourism is highly controversial. Slum tourists are often accused of voyeurism, even though the slum tourism literature has not yet clearly determined what this might mean (Selinger and Outterson 2009). While unethical practices are reported in various case studies (Freire-Medeiros 2009; Rolfes, Steinbrink and Uhl 2009), the central ethical problem of slum tourism seems to be based on the assumption of radical power difference between the tourists and the visited poor. As tourists gaze upon the poor, Urry's (2002) critique of the post-colonial character of tourism seems to be fundamentally confirmed. But is it really always problematic to look at poverty, and do such criticisms also apply to international activists, who also visit poverty-stricken areas when they travel to slums to intervene and 'make poverty history'?

The chapter is divided into two parts. In the first section I present three empirical cases, in which the development of recent slum tourism can be traced back to forms of political 
tourism. Highlighting overlaps and differences between the three cases, I propose a developmental model of the genesis of slum tourism. In the second section I discuss the implications of the model for the discussion of the ethics of slum tourism. I chart the ethical controversies over slum tourism, focusing on two moral concerns: voyeurism and the visitors' interventions. This is followed by a discussion of the different ways in which these concerns are addressed when international visitors visit slums. On the basis of this reflection I conclude by answering the initial question: does slum tourism have a political core?

\section{South Africa: from 'junkie struggles' travels to township tours}

The first case presented here is the development of township tourism in South Africa. Already under the apartheid regime, township tours were offered as an official tourist attraction by the state. This served political purposes, as these visits were meant to portray a picture of untroubled race relations in the apartheid regime. Dondolo (2002) reports that they developed from tours organized by state agencies for local government officials in order to portray the benevolent character of townships, displaying them as 'ethnic villages in the city'. Apart from the 'official' tours, critical NGOs and political groups organized tours for "local whites, international funders and struggle junkies" (Pirie 2007: 235). 'Struggle junkies' is a curious term, originally used by Dondolo (2002). It contains a significant value judgement. It indicates the somewhat dubious role of international political activists who come to other countries to join local and national struggles. The notion of 'struggle junkies' seems to indicate that such visitors engage in a rather selfish pursuit, a voyeurism fuelled by interest in the sight of people struggling rather than in the cause of the struggle itself. Such a critical notion is surprising, as, arguably, the struggle against apartheid in South Africa has been greatly helped by international solidarity networks (Seidman 2000). Were the unofficial tours of the apartheid period not part and parcel of the intervention of international solidarity activists to support the struggle against apartheid? 
With the end of the apartheid regime in 1994, interest in visiting the townships grew. The unofficial tours of the apartheid period became the first township tours of the post-apartheid system. Initially, post-apartheid township tours were explicitly constructed as 'political tourism' (McEachern 2002), highlighting ongoing struggles and injustices in the developing democracy. In the years following, and in the context of a growing tourism industry in South Africa, the township tours increasingly took on the form of heritage tours, reflecting the role of townships in the revolutions leading towards the 1994 regime change. This included visits to Soweto as a place symbolizing oppression and the anti-apartheid struggle, their aim being to see the sites of resistance and the houses in which symbolic figures like Nelson Mandela and Bishop Desmond Tutu used to live (Steinbrink 2012). In the following years, the historical and political aspects which had initially been the focus shifted to the background, and townships increasingly came to be presented as cultural attractions (Rolfes et al. 2009). Controversies occurred as to whether such displays of 'townships' would not be demeaning (Shepherd and Hall 2007). But such concerns were rebutted in the hope that tourism would provide a form of poverty relief in the new 'Rainbow' nation.

Furthermore, township tours have been highlighted as an indication of non-white entrepreneurship (McEachern 2002). In this vein, township tourism is openly promoted by South African governments on both local and national levels. Although the effectiveness of township tourism to reduce poverty in the townships as a whole may be limited, undoubtedly some have benefitted financially (Rogerson 2004; Koens in this volume). As Rolfes et al. (2009) have shown, township tours have become a tourist 'must', certainly in the Cape Region. Township tours are attended by up to $25 \%$ of Cape Town visitors, with similar developments in other large South African cities (see also Koens in this volume). Township tours have now become a normal feature of tourism in the country. 
The development of township tours followed an interesting route. In the apartheid period, tours were highly politically charged, albeit in different ways: the official tours were part of the political propaganda of the regime and were designed to brush over the conflicts and oppression by highlighting cultural diversity and 'happy' 'black' township life (Dondolo 2002). The unofficial tours were also political, but in the opposite way. They brought international activists into the anti-apartheid struggle. The fact that these visitors were sometimes called 'struggle junkies' shows the problematic nature of their intervention. In the post-apartheid area, tours are less controversial (see Butler in this volume). The focus of many tours has started to include those 'cultural' aspects that were at the core of apartheid township tourism, whereby townships are now increasingly valued as places that display cultural diversity, something positive, rather than poverty and exclusion and the ongoing struggles against them.

\section{Rio de Janeiro: the Earth Summit and the favela tour}

The origin of the Rio favela tours is contested and different account exists who offered those tours first. However it is uncontested that the development of the phenomenon was started by a specific political event, the Rio summit of 1992 (Freire-Medeiros 2009). The Rio summit is mainly known for bringing forward the sustainability agenda. It is worthwhile to remember that it stood at the beginning of a new wave of transnational politics, enabled by the collapse of the Soviet Bloc. It also marked the beginning of a new form of transnational, grassroots politics, made possible by unprecedented levels of international mobility and communication in the context of globalization. The Rio summit was attended by 178 government delegations, but also by over 30.000 other participants, including NGO workers, activists and the media (Najam and Cleveland 2005). The high number of attendees was probably the most important feature of this new form of international conference. Indeed, the development of event-based political tourism can be dated back to the Rio summit. 
During the summit, participants started exploring Rio, either as tourists or to find stories to report about. On their tours to more conventional tourist sites of Rio, summit participants passed by Rocinha, Rio's largest favela, located between the world-famous beaches and sights like the Corcovado Jesus Statue. The entry points to Rocinha and other favelas in the inner city areas had an unusually high police presence, arguably to shield the conference off from the periodically erupting violence in these favelas. Socially conscious 'political' tourists, however, demanded to know more about the favelas and also inquired whether it was possible to visit them specifically. Tour operators responded to the demand and took the conference participants into Rocinha. Some of these visits are documented in journalist articles written about the favela in the context of the Rio conference (Anon 1992). To use a term from Bianca Freire-Medeiros (2009), the favela 'started travelling', and 'favela' became a concept known globally, far beyond the confines of Brazilian society.

A more immediate effect, however, was the establishment of the first commercial favela tours in Rio. After the end of the Rio Summit, the operators were increasingly able to sell their tours among mainstream Rio tourists. The developing business of favela tours initially caused controversy in Rio and the wider Brazilian society. The tours were accused of being voyeuristic and exploitative of the poor living in the favela (Freire-Medeiros 2009). The tour operators were quick to find 'ethical' fixes against these claims of exploitation, mainly by linking their tourism work to charitable engagement in the favela, for which they provided funding from the profits of the tour. It also became increasingly clear that the 'favelados' of Rocinha were puzzled by the visiting tourists but also generally welcoming. These findings refute the charges of voyeurism (Freire-Medeiros in this volume). In this light it becomes interesting to reflect on the motives behind the initial criticism that the tours provoked. To what extent did such criticism - voiced by local elites - reflect Brazilian class politics? The Brazilian history of the favela is complex; however, one central aspect has been the neglect 
and stigmatization of people living in the favela (Frisch 2012). The interest of international travellers in the favela pointed at a social problem to which the Brazilian society so far had not managed to find an answer. In this light the initial criticism of favela tourists might bear some similarity to the criticism of township visitors as 'struggle junkies'. As members of a post-colonial society, Brazil's elites rejected the intervention of international tourists into what they might have considered 'their' social question. To dismiss international tourists' motives as voyeuristic was arguably also a way of questioning their right to intervene into Brazilian internal affairs even if that intervention did not extent much beyond increasing the visibility of the favelas.

The development of favela tours into a tourist 'must-do' in Brazil in the years following the Rio summit has many causes. Crucial were two internationally received films about favelas in Rio, the City of God (2003) and Favela Rising (2005) (Freire-Medeiros 2009). Their popularity among audiences in the US and in Europe extended the phenomenon of the 'travelling favela', with the development of 'favela chic' nightclubs (Freire-Medeiros 2009) and other related phenomena in the West (Linke 2012). Today Rio has several tour operators who offer favela tours. Freire Medeiros (2009) estimates that the favela of Rocinha receives up to 3.000 tourists per month. Parallel to this development there has been a remarkable change in attitude by Brazilian society towards favela tourism. While scepticism among elites might persist, the political class has started to embrace it. In 2000, the mayor of Rio attempted to create a heritage museum in the favela of Morro da Providência (Menenzes in this volume). As recently as August 2010 the state of Rio has embarked on a specific programme to create favela tourism in a variety of favelas, which was endorsed even by ex-president Lula (MSNBC 2010). These operations have to be seen in the context of a larger favela 'pacification' programme in which a variety of inner city favelas have been taken over by special police forces in a controversial push for security in advance of international sporting 
events coming to Rio (Barrionuevo 2010). Despite this broader context of security, favelas are arguably increasingly seen as a cultural asset, while tourism to these areas is affirmed and promoted as a source of development and income in some of the poorer neighbourhoods of Rio (Frisch 2012).

\section{Nairobi: off the beaten track at the World Social Forum}

In Nairobi, yet another political event, the World Social Forum (WSF), initiated the rise of slum tourism in the massive slum of Kibera. There is so far limited research about this case of slum tourism, and I base my arguments here largely on my own observations as an attendee of the WSF and slum visitor to Kibera and other Nairobi slums.

In January 2007, Nairobi hosted the WSF, an annual gathering of social movement activists and NGOs designed as a counter event to the World Economic Forum in 2001(WSF 2006). Like the Rio summit, it can be understood as an event attracting scores of international political tourists. The Nairobi WSF brought together about 20.000 to 30.000 international visitors (Mbugua and Ongwen 2005; Wolfson 2007).

Nairobi is the African headquarters of the UN and hosts international summits on a regular basis. The city's infrastructure is prepared for such events, providing guests with world-class hotels and other facilities that stand in blatant contrast to the living conditions of millions of Nairobi's inhabitants who live in slums. The WSF is unique as an international conference because of its grassroots approach, embracing the idea of pursuing democratic political processes on a global level, a 'globalization from below', with maximum inclusivity. Most of the Nairobi WSF took place in the official surroundings of a large football stadium. And many international delegates were indeed housed in first-class hotels in downtown Nairobi. Because of the politics of the WSF, many of the international delegates took issue at the 
exclusivity of the event and demanded that the WSF connect more with the poor living in Nairobi. Indeed, as poverty featured so strongly as a topic, there were a variety of discussions on how to relate best to the poor. One of the most significant issues concerned the openness of the forum to Nairobi's poor. As the WSF required the purchase of a ticket to cover the organizational costs, and tickets for Kenyans were priced at 3 US\$, most of the urban poor were effectively excluded from the WSF. The WSF itself had strong security (already an omnipresent feature in Nairobi), with heavily armed guards and policemen securing the gates of the event. Licensed caterers provided food and charged international prices unaffordable to the local poor. Local organizers justified the set-up as a result of limited government support for the event. In contrast to Brazil and India, where the WSF had taken place previously, local and central government did not support the WSF in Nairobi financially. Not dissimilar to delegates at the Rio summit in 1992, participants of the WSF contested the exclusion of the poor, and one of the immediate outcomes was the significant drive of many international delegates to move from the locations of the WSF to the poor neighbourhoods. The slum of Kibera, which had gained attention through international documentaries and films like The Constant Gardener (2006), and is often called the biggest slum of Africa, was a principle choice. The visits of delegates to the slums were organized by NGOs that operated locally with projects in Kibera, and offered to take delegates with them to see their projects. The visits to Kibera developed into a 'must-do' at the WSF throughout its duration. As more and more delegates joined the spontaneously organized tours, delegates started to see each other touring Kibera. At the same time, other slums were 'discovered' as new sights. Participants in these visits often praised the fact that these slums were 'off the beaten track' compared to Kibera, and offered a 'more authentic' picture of poverty.

Conflicts about the inclusion of the poor into the WSF persisted to the end of the forum involving protests of delegates against the local organizing committee (Oloo 2007). The 
Nairobi WSF is remembered as one of the most controversial events in WSF history. The other legacy of the WSF is the creation of slum tours in Kibera. Mowforth and Munt (2009) have argued that the WSF had created an infrastructure that persisted even after the social forum was over, and that the political event there stands at the beginning of the development of organized slum tourism. Today there are a variety of operators.

Controversies and criticism have focused on the issue of voyeurism (Odede 2010). So far there has been little indication of a particular rejection of slum tours from Kenyan elites. However there was some clear indication of criticism from Kenyan middle classes towards the burgeoning slum tours during the WSF. The main accusation was that the international visitors romanticized poverty and lacked the ability to understand the specific local configuration of poverty. I have discussed this and other criticism of western WSF participants' urge to visit and relate to the slums of Nairobi elsewhere (Frenzel, Boehm, Quinton, Sullivan, Spicer and Young 2011).

\section{A developmental model of slum tourism locations}

As indicated earlier, one of the central questions for slum-tourism research is why it occurs in some places and not in others. While it is not possible to answer this question based on the three cases (South Africa, Kenya and Brazil) discussed here, there is a clear indication that politically motivated international tourists play an important role in the development of slum tourism. The destination countries also show some macro-political parallels. In all three cases the political context is one of post-colonialism, involving states that in different ways are trying to throw off their colonial past. All three countries display significant levels of inequality among their populations, both economically and in terms of social and political rights. In the last two decades - the period in which slum tourism has developed in these countries - all three countries have democratized significantly. They have also attempted to 
develop economically, with tourism as a significant factor in their economic development strategy. Their strategies have met with variable success, as poverty has remained a central problem in all three countries.

The frequency and political influence of international political travel in the last two decades is very different, however. While both Kenya and Brazil will have seen some influx of international activists to support their democratic change, their struggle for democracy has never been internationalised to the same extent as South Africa. Rather than a political revolution in the making, the initial trigger of slum tourism in Nairobi and Rio were events that were less particular to the host cities or countries, but which concerned global issues. Still, in both cases the host cities provided more than a location for the event, they both started functioning as a case study for the global issues under discussion. It is in this way that the slums of both cities were 'discovered' by international political tourists. They became spaces of intervention, of applying the content of the global concern to practical, local conditions much in the same way that the South African struggle offered itself as a space of intervention for international activists.

In all three cases the interventions were contested by local elites. Of course there is a world apart between the hostility of the white elite in South Africa against 'struggle junkies', who helped challenge the status quo of the apartheid regime, and the uneasiness that Brazilian and to a lesser extent Kenyan elites display in the face of international visitors who highlight the plight of the respective countries' poor. The principal ethical question seems to be parallel, however. What conditions justify the intervention of political tourists into domestic issues, or when do 'domestic' issues become a legitimate international, global concern? 
Leaving this question open for now, I would like to point out further parallels in the development of organized slum tourism in all three cases. Arguably they show different stages of parallel development. This concerns not only the initial genesis of slum tourism emerging from political travellers' visits to the slums, but also from the fact that there are different levels of controversy over this intervention, often triggered by the scepticism of local elites. It is also significant that in both the South African and the Brazilian cases these controversies were overcome to some extent as the tours became more established as tourist 'must-dos'. In particular it is significant how various local and national policy makers in both countries have started to actively promote tourism in poor neighbourhoods as part of regeneration and poverty alleviation policies targeted at these areas. Both cases also show a shift of discourse in which the tours are promoted. Rather than only promoting the tours as a tool of poverty relief and regeneration, they are also framed in cultural terms. The slums and townships are advertized as places that are culturally different, provide insights into the 'authentic' backstage of the respective cities and add to the diversity of the place. Indeed, this shift in discourse is maybe the most significant difference between the initial slum visits of political activists to the commercialized tours that followed.

This indicates that the development of commercialized slum tourism out of politically motivated travels functions as a mechanism by which the respective local elites cope with the intervention of international political travellers into their politics. Highlighting social and political inequalities and lending visibility and voice to the disenfranchised, political travellers can significantly help challenge the status quo of the societies they visit. Fundamentally they demand an answer to the inequality they encounter. Political conflicts around the world demonstrate how states react differently to such a challenge. Short of an answer, they may attempt to keep international visitors out. They may attempt to undermine the legitimacy of 
the intervention of international political tourists by questioning their motives or their position, particularly if the visitors come from former colonial countries.

However, they can also provide an answer in the way the discussed cases indicate. By creating a narrative of development in which slum tourism becomes a crucial part, they successfully justify the inequality that is 'not yet' overcome. Moreover, they may shift a discourse of inequality into one of cultural difference. The slums become 'other' places in a good sense; they are portrayed as more 'authentic' and hence valuable in the way they are. This entails yet another justification of the state of poverty they are in, and therefore provides answers to the questions that slum-visitors pose to countries that have not managed to eradicate slums.

I am not arguing that the development of slum tourism is a deliberate plot to prevent social change by elites in the respective countries. Rather, this is to point towards the mechanism by which to explain the shift towards the appraisal of internationals interested in the 'problems' of a visited society in two of the discussed cases. In the next part I would like to highlight why this discursive shift equally appeals to tourists themselves. For the tourists not only face the ethical challenge of being called voyeurs, they must also justify their intervention, and the fact that they point towards problems abroad, outside their home polities.

\section{Politics and ethics of slum tourism}

The ethical controversies concerning slum tourism are often framed as voyeurism, and slum tourists are accused of engaging in 'poverty porn' (see Basu in this volume), transforming the plight of other people into a spectacle. As indicated earlier, the moral concerns of slum visits by political travellers go further. The fundamental question for international activists addressing poverty in countries they visit is: on what grounds can their intervention be 
justified? In the following section I reflect on these two very different moral concerns, starting off by an analysis of the accusation of voyeurism. At the bottom of this accusation is a phenomenon of tourism that Urry (2002) has theorized as the tourist gaze. Urry takes a cue from Foucault's (1979) notion of the gaze as a tool of surveillance and control, a mechanism of power. Urry provides an application of Foucault's complex philosophical argument, focusing on the ways tourists are subject to certain specific and historically predefined 'gazes' onto landscape, nature and people. He differentiates in particular between a romantic and a collective gaze, broadly aligned with the two major British social classes and their pursuit of tourism. While the collective gaze, broadly confined to working-class holidays, casts landscapes of sand, sea and sun where tourists remain happily among themselves, the romantic gaze of the middle classes charts the landscapes of tourism for the romantic encounter of the tourists with the 'other', be it in nature or people. Ideally, the romantic gaze figures a lonely traveller discovering the 'other' in search of the true and authentic nature of the self. In evoking and charting the 'other', the development of the romantic gaze is strongly influenced by the imaginaries of colonialism. The 'othering' of people encountered in the European conquest of the world and its function in building and identifying the 'West' has been broadly discussed (Said 2001; Pratt 2008). Suffice to say that international tourism is embedded into a post-colonial context in which 'othering' is combined with radical differences in income, power and mobility between the visitors and the visited. By placing the romantic gaze in the context of power and colonialism, it is important to reflect that 'the other' is able to gaze back (Hendry 2000). In Freire-Medeiros' observations on Rocinha (in this volume), this 'reverse gaze' is clearly documented. However, the accusation of voyeurism remains based on the idea that tourists cast a powerful gaze upon the less powerful in the pursuit of 'otherness'. The 'otherness' is consumed with little or no advantage for the 'othered' people. Slum tourism arguably mirrors the logic of the romantic gaze in 'othering' slum dwellers and their lives. 
Steinbrink (2012) has taken a closer look at the different ways in which slum tourists have 'othered' the poor in the history of slum tourism. He determines three periods that he calls 'moral slumming', 'ethnic slumming' and 'global slumming'. All three are linked to particular periods and places and to different ways of 'othering'. For Steinbrink, the key to understanding the logic of 'othering' is the dichotomies of attraction/repulsion and fear/desire. The first period, or moralist version, of 'othering' is linked to Victorian slumming, and displays an understanding of the slum as attractive/repulsive because of its moral ambiguity. The slum is constructed and 'othered' as a space of dirt, with its double implication of hygienic and moral deviance. In the second period, the American slumming of the early $20^{\text {th }}$ century, slum dwellers are 'othered' as 'ethnic' immigrants, reflective of the role that growing communities of new immigrant groups played in cities of the US. The slum is attractive/repulsive in respect of the ethnic difference that is territorialized in it. Steinbrink places the most recent wave of slum tourism in the South, in the context of globalization. He argues that slum dwellers are construed as 'locals' (opposed to the global traveller), and the slum as a resort of locality, authenticity and uniqueness that makes them special in the eyes of the 'globalized' tourist. It is important to add that there is evidence of the various different forms of 'othering' in all forms and periods of slum tourism. Indeed, cultural differences played a significant role in London's nineteenth-century slumming discourse, where slum residents were often 'othered' as Irish or Welsh immigrants (Seaton in this volume). And 'othering' in the context of Brazilian favelas often takes the form of moral repulsion/attraction when favelas become places of samba, sex and (illicit) substances. These overlaps confirm Steinbrink's argument that 'othering' is a central mechanism of slum tourism or rather of the way slum-tourists view the slums. In regard of the cases discussed above, what forms of 'othering' can be identified? 
The development of more broadly consumed forms of slum tourism, South African township tours and favela tours resulted in a stronger emphasis on the cultural uniqueness of these places. Advertized by tourism agencies and promoted by local government, poor areas are recast as valuable places to visit not because they provide an insight into the plight of the poorest, but rather because they allow the tourists to appreciate the unique qualities of these places. As Meschkank (in this volume) argues, a semantic transformation takes place in which the slums are redefined in a positive manner. This value can take many semantic forms: it can be seen as 'simple', 'cultural' or 'local'. Crucially, this value can be exchanged, which then enables the seemingly unlikely 'commodification of poverty' (Freire-Medeiros 2009) in slum tourism.

The transformation of the slum into something valuable fulfils another, moral, function for the tourist. If poverty is understood as a problem, gazing at it evokes the necessity to do something about it. Indeed, voyeurism means that poverty is simply consumed for entertainment with no regards for the poor; they are simple 'othered' as poor. However, if poverty can be seen as something valuable, touring it becomes a 'must-do' just like other valuable sights need to be 'seen'. Arguably this is what has happened in the most developed slum tourism destinations. 'Othering' is recast in a positive light: the poor are 'others', but they are good! Concurrently there is less need to do something about their poverty. Earlier I described the developmental model of slum tourism in which South African and Brazilian elites have started to embrace slum tourism. One crucial element in this transformation consists of shifting the value of what is being visited. Rather than framing slums as a weakness, they become an asset (for example as a sign of diversity) of a place. We can now see that this transformation is equally attractive for tourists who are facing the accusation of being voyeurs or of casting a powerful 'othering' gaze onto the poor. In 
celebrating the 'othered' poor as valuable, the tourists may find a route to refute the accusation of voyeurism.

In order to take this argument further, let us turn to the second moral concern, the problem of 'intervention'. This problem seems to be limited to political tourists, assuming that nonpolitical tourists are not interested in the intervention in the first place. Two questions arise. Firstly, how can non-political tourists not be interested in an intervention? What justifies their decision not to intervene, considering what they see is poverty? Secondly, on what grounds can the intervention of those travellers who do intervene or consider intervening be justified? The answers to both of these questions are closely related. In order to intervene, political travellers are in need of an ethical discourse or a set of norms that apply equally to them and the countries they visit in order to be able to make an intervention. The eradication of poverty is widely considered a universal norm, and this is reflected not only in universal norms per se but in most national legal frameworks and policies as well. The problem in invoking the universal norm of poverty eradication as an international visitor, then, is not so much an issue of norm relativity. The problem seems to be rather that in the act of invoking the problem of poverty in a visited country, the visitor creates a universal political context in which she becomes part of the problem. That is, if the problem of poverty is universal, the international visitor is immediately confronted with her own privilege, the ability to leisurely travel internationally in the light of poverty. Many tourists who are visiting the slum are very unlikely to intervene, because any criticism of the visited country and its inability to deal with the social problem of poverty will fall back onto the privileged tourist. In order to point to the slums as a social issue that needs addressing, the slum visitor will have to consider income inequality not only within the visited country but also on a global scale. 
Looking at the cases I discussed earlier, it is important to point out how they differ in this respect. The intervention of international activists into the South African apartheid regime could be justified by recourse to the universal norms of democracy and human rights and to the extent that South Africa was denying democratic rights to the majority of its population. As visitors considered themselves to be democratic, their inclusion into the normative context in which they judged the South African regime did not question their own position.

International visitors who point towards income inequality in the visited country often argue in a similar way, claiming that local elites are failing to address the issue of poverty in their countries. However, it is arguable that such a view is harder to sustain without reflecting on the privileged position the travellers are in. At the very least their appeal for social justice would evoke demands for them to share their wealth. If political travellers want to address poverty in a foreign country they have to fall back on a universal normative discourse from which the visitors' own position cannot easily be excluded.

In the cases of visitors to the Rio summit in 1992 and the WSF in 2007 in Nairobi, political travellers in the slums often resorted to the global economic status quo, as theorized in dependency theory (Wallerstein 2004), as a critique of globalization or neo-liberal global capitalism (Hardt and Negri 2000; Kingsnorth 2003; Harvey 2005). Those theories provide powerful narratives that place the poverty that visitors encounter and their own privilege in the same normative discourse. Concurrently they are often highly critical of the global economic and political status quo. Slums can be understood as evidence supporting this critique of the political and economic status quo. In this context the visits to the slums are justified, as they allow for the collection of evidence and alignment with slum dwellers in their fight against the global status quo. 
This is without a doubt very similar to the way better-off political activists have attempted to justify visiting slums over the last three centuries. It is, however, markedly different to the logic of justification that reframes poverty as a valued 'other'. Indeed, in one instance the poor are 'othered', their difference emphasized and manifested. In another instance the poor are 'same-d' - integrated into the normative and political context in which the visitors also act. They are not - for better or worse - 'other'; they are the same.

Looking at the three cases described earlier, how do we explain the transformation of visits of political travellers, arguably interested in addressing poverty as a global issue, into slum tourism, where the slums and slum dwellers are 'othered' as culturally valuable? Arguably the distinctly different answers to the ethical problem of visiting slums, namely 'same-ing' and 'othering', conflate in the practice of political travellers. The case of Nairobi showed how political activists started debating the authenticity of different slums as tours to Kibera became increasingly popular. Value was placed on the unique 'otherness' of the alternative slums in so far as few other visitors had yet tainted them. Similar observations can be drawn from other cases of political travels into poverty and slums. Hutnyk (1996) has described and criticized the way in which travellers need to construct Kolkata as a place of poverty in order to justify their charitable engagement. While the 'othering' here does not give positive value to the slum in the ways described above, it enables an intervention that is not political but charitable. In the same way that slum tourism is often promoted and presented as the solution to poverty, this form of 'othering' follows a post-colonial logic in which the visitor is not part of the problem, but brings and manifests the solution.

Even cases of literary slumming, which describe the practice of representing slums in literature or film (Williams 2008 and Seaton in this volume), show the trap of 'othering' that even highly political authors arguably fall into. Davis' broadly received 'planet of slums' (2006) was intended to be a vociferous critique of the current economic status quo. However 
it has drawn substantial criticism for a representation of global poverty that evoked imaginaries of hopeless, apocalyptic and fundamental 'otherness' (Pithouse 2008; Angotti 2006; Harding 2007).

\section{Conclusion}

In this chapter I have presented three contemporary cases of slum tourism. In all three cases the travels of political activists to the slums predate and initiate the development of slum tourism. The three cases also show further parallels that point towards a developmental model of slum-tourism destinations. At the beginning stands the intervention of international political travellers into foreign countries' political affairs, in particular into their 'social question', the problem of inequality and poverty. Slum tourism infrastructure develops in all three cases in the footsteps of services provided to political travellers who visited slums. With the increasing visibility of slum tourism, controversies occur, triggered mostly by criticism from domestic elites who denounce slum tourists as voyeurs and slum tourism operators as exploiters of the poor. Slum-visitors are also questioned on the basis of their positioning: for example, if they originate in former colonizing countries. There are also questions with regards to their own privilege vis-à-vis the poverty. In two of the described cases the initial hostility falters as the destinations mature. Following the development model this would indicate that a similar process should be observable - for example in Nairobi, but also in other developing slum tourism destinations, such as Mumbai or Bangkok.

It furthermore remains to be discussed why the hostility falters. My findings indicate that this has to do with a shift in the discourse of slum tourism, observably taking place parallel to increasing acceptance, in which the political features of the slum tourism give way to cultural ones. This includes the increasing dominance of forms of 'othering', in which the slums and slum-dwellers are portrayed less as a problem and more as an asset of the visited city/country. 
This shift enables local elites to embrace slum tourism, but it also fulfils important functions for the slum tourists. Indeed, the pressing moral and political questions of global inequality that particularly arise in global tourism can be safely managed in slum tourism. Poverty may be translated into cultural difference that can be valued for what it is. It may also be portrayed as a subject of development in which slum tourists may see themselves as a solution to the problem they observe. In all cases, slum tourism operates as 'othering' and creates distance and difference between the visited and the visitors.

I have argued that there is a different option for travellers visiting the slums. Indicated by the approach some tourists could take when visiting slums, an intervention can also be justified if the slum-residents are not 'othered', but 'same-d'. This would be based on narratives critical to the global economic order that produces the obscene inequalities we currently live with. It may also involve creating networks of resistance and solidarity with slum-dwellers that enable reciprocity in the North-South mobility via reverse visits.

Slum tourism seems to have developed out of political travels, and this indicates that political travels are not always successful in solving the moral questions that result from visiting the slums. I have shown that 'othering' is a fundamental part the visits of political travellers in literal and literacy slumming. It is therefore without merit to disqualify slum tourism simply on the grounds that it provides false relief for the moral concerns of tourists.

In the eighteenth and nineteenth centuries, the first examples of slum tourism developed parallel to the formation of the 'social question', the political concern about how to deal with and end poverty, then a national question. There is no space in this chapter to develop the multiple links between the activities of philosophers, social revolutionaries, social entrepreneurs and commercial tour guides in the slums of the developing urban centres of the 
throughout this period. Both Seaton (in this volume) and Koven (2004) have done some work on disentangling these connections, indicating the close relation of the development of social and welfare policy in the late nineteenth century and the increasing attention slums received at the time. Further research is needed to address the way that the current forms of "global slumming" (Steinbrink 2012) might be an indication of the development of a global social question. Slum tourism does not seem to be an appropriate answer, but it arguably shows that there is a growing interest in responding. 


\section{References}

Angotti, T. (2006) 'Apocalyptic anti-urbanism: Mike Davis and his planet of slums', International Journal of Urban and Regional Research, 30(4): 961.

Anon (1992) Rio's poor make their point', New Scientist 20 June 1992. Online. Available HTTP: <http://www.newscientist.com/article/mg13418260.600-rios-poor-make-theirpoint.html> (accessed 8 October 2011).

Babb, F. (2004) 'Recycled sandalistas: From revolution to resorts in the new Nicaragua', American Anthropologist, 106(3): 541.

Barrionuevo, A. (2010) 'In rough slum, Brazil's police try soft touch', The New York Times. Online. Available HTTP:

<http://www.nytimes.com/2010/10/11/world/americas/11brazil.html?_r=1> (accessed 8 October 8 2011).

Brin, E. (2006) 'Politically-oriented tourism in Jerusalem', Tourist Studies, 6(3): 215-243.

Davis, M. (2006) Planet of Slums, London: Verso.

Dondolo, L. (2002) The Construction of Public History and Tourism Destinations in Cape Town's Townships: A Study of Routes, Sites and Heritage, Cape Town: University of the Western Cape.

Foucault, M. (1979) Discipline and Punish: The Birth of the Prison, London :Vintage Books. 
Freire-Medeiros, B. (2009) 'The favela and its touristic transits', Geoforum, 40(4): 580-588.

Frenzel, F. (2009) 'Politics in motion. The mobilities of political tourists', unpublished PhD thesis.,Leeds Metropolitan University.

Frenzel, F., Boehm, S., Quinton, P., Sullivan, S., Spicer, A. and Quinton, P. (2011)

Comparing alternative media in North and South: the cases of IFIWatchnet and Indymedia in Africa, Environment and Planning A, 43(5): 1173-1189.

Frisch, T. (2012) 'Glimpses of another world: the favela and its transformation from a "social exclusion area" into a touristic attraction', Tourism Geographies 14(2), forthcoming.

Gumbel, N. (ed.) (2005) Make Poverty History, London: Alpha International.

Harding, J. (2007) 'Planet of slums', The London Review of Books., 29(5): 25.

Hardt, M. and Negri, A. (2000) Empire, Cambridge, MA: Harvard University Press.

Harvey, D. (2005) A Brief History of Neoliberalism, Oxford: Oxford University Press.

Henderson, J. (2007) 'Hosting major meetings and accompanying protestors: Singapore 2006', Current Issues in Tourism, 10(6): 543-557.

Hendry, J. (2000) The Orient Strikes Back: A Global View of Cultural Display, Oxford: Berg.

Hutnyk, J. (1996) The Rumour of Calcutta: Tourism, Charity, and the Poverty of Representation, London: Zed Books. 
Kingsnorth, P. (2003) One No, Many Yeses: A Journey to the Heart of the Global Resistance Movement, Montreal: Free Press.

Koven, S. (2004) Slumming: Sexual and Social Politics in Victorian London, Princeton, NJ: Princeton University Press.

Linke, U. (2012) 'Mobile imaginaries, portable signs: the global consumption of iconic representations of slum life', Tourism Geographies 14(2), forthcoming.

Mbugua, B. and Ongwen, O. (2005) 'Nairobi to host global civil society forum'. Online. Available HTTP: <http://www.eastandard.net/archives/cl/print/news.php?articleid=25274> (accessed 15 March 2007).

McEachern, C. (2002) Narratives of Nation: Media, Memory and Representation in the Making of the New South Africa, Cape Town: Nova Publishers.

Mowforth, M. and Munt, I. (2009) Tourism and Sustainability: Development, Globalisation and New Tourism in the Third World, 3rd edn, London: Routledge.

Moynagh, M. (2008) Political Tourism and its Texts, Toronto: University of Toronto Press.

MSNBC (2010) 'Brazil wants tourists to visit Rio slums - Travel - Destination Travel - South America'. Online. Available HTTP: <http://www.msnbc.msn.com/id/38922800/ns/traveldestination_travel/t/brazil-wants-tourists-visit-rio-slums/\#.TpB1nU8Y5wc> (accessed 8 October 2011). 
Najam, A. and Cleveland, C.J. (2005) 'Energy and sustainable development at global environmental summits: an evolving agenda', in L. Hens and B. Nath (eds) The World Summit on Sustainable Development: The Johannesburg Conference, New York: Springer Science \& Business.

Odede, K. (2010) 'Slumdog tourism', The New York Times. Online. Available HTTP: <http://www.nytimes.com/2010/08/10/opinion/10odede.html> (Accessed 8 October 2011).

Oloo, O. (2007) 'OpenSpaceForum $\square$ : critical reflections on WSF Nairobi 2007', Open Space Forum. Online. Available HTTP: <http://www.openspaceforum.net/twiki/tikiread_article.php?articleId=392> (accessed 8 October 2011).

Pezzullo, P. (2007) Toxic Tourism: Rhetorics of Pollution, Travel, and Environmental Justice, Tuscaloosa: University of Alabama Press.

Pirie, G. (2007) 'Urban tourism in Cape Town', in C.M. Rogerson and G. Visser (eds) Urban Tourism in the Developing World: The South African Experience, Cape Town: Transaction Publishers.

Pithouse, R. (2008) 'Mike Davis, Planet of Slums'. Book review, Journal of Asian and African Studies., 43(5): 567.

Pratt, M.L. (2008) Imperial Eyes: Travel Writing and Transculturation, London: Taylor \& Francis. 
Rogerson, C.M. (2004) 'Urban tourism and small tourism enterprise development in Johannesburg: the case of township tourism', GeoJournal, 60(1): 249-257.

Rolfes, M. (2009) 'Poverty tourism: theoretical reflections and empirical findings regarding an extraordinary form of tourism', GeoJournal, 75(5): 421-442. Online. Available HTTP: <http://www.ingentaconnect.com/content/klu/gejo/2010/00000075/00000005/00009311> (accessed 20 January 2011).

Rolfes, M., Steinbrink, M. and Uhl, C. (2009) Townships as Attraction: an Empirical Study of Township Tourism in Cape Town tsverl. Potsdam.

Said, E. (2001) Orientalism: Western Conceptions of the Orient, 5th edn, London: Penguin.

Scheyvens, R. (2002) Tourism for Development: Empowering Communities, Upper Saddle River, NJ: Prentice Hall.

Seidman, G.W. (2000) 'Adjusting the lens: what do globalizations, transnationalisms, and the anti-apartheid movement mean for social movement theory?' In J.A. Guidry, M.D. Kennedy and M.N. Zald (eds) Globalizations and Social Movements: Culture, Power, and the Transnational Public sphere. Ann Arbor, MI: University of Michigan Press.

Selinger, E. and Outterson, K. (2009) 'The ethics of poverty tourism'. Boston School of Law Working Papers. Online. Available HTTP:

<http://www.bu.edu/law/faculty/scholarship/workingpapers/documents/SelingerEOuttersonK 06-02-09.pdf > accessed $27^{\text {th }}$ October 2011. 
Shepherd, N. and Hall, M. (eds) (2007) Desire Lines: Space, Memory and Identity in the PostApartheid City, London: Routledge.

Steinbrink, M. (2012) 'We did the slum! Reflections on urban poverty tourism from a historical perspective', Tourism Geographies 14(2), forthcoming.

Urry, J. (2002) The Tourist Gaze, 2nd edn, Thousand Oaks, CA: Sage Publications.

Wallerstein, I.M. (2004) World-Systems Analysis: An Introduction, Duke: Duke University Press.

Williams, C. (2008) 'Ghettourism and voyeurism, or challenging stereotypes and raising consciousness? Literary and non-literary forays into the favelas of Rio de Janeiro', Bulletin of Latin American Research, 27(4): 483-500.

Wolfson, C. (2007) 'Kenyans unite with foreign allies at WSF' rabble.ca. Online. Available HTTP: <http://www.rabble.ca/news/kenyans-unite-foreign-allies-wsf> (accessed 29 January 2009).

WSF (2006) 'Fórum Social Mundial', History of WSF. Online. Available HTTP:

<http://www.forumsocialmundial.org.br/main.php?id_menu=2\&cd_language=2> (accessed 8 October 2011). 